\title{
PEER-LED TEAM LEARNING (PLTL), STUDENT ACHIEVEMENT AND ENGAGEMENT IN LEARNING CHEMISTRY
}

\author{
Omar Gonzales Lamina (Casimiro A. Ynares Sr. Memorial National High School, \\ Philippinnes) \\ laminaomar@yahoo.com
}

\begin{abstract}
The main purpose of this study was to determine the effects of the Peer-Led Team Learning (PLTL) strategy on the achievement and engagement of students in learning Chemistry. It was conducted at Casimiro A. Ynares Sr. Memorial National High School, Taytay, Rizal during the second quarter of the school year 2019-2020. The participants of this study were chosen using purposive sampling. The sample students belong to one intact section of Grade 9 composed of 36 students. Two students from the class served as the peer leaders that facilitated the workshops for five weeks. This study utilized a one-group pre-experimental research design. The results revealed that there is a significant difference in the chemistry achievement and the engagement mean scores of the students before and after their exposure to Peer-Led Team Learning. A significant difference was found in all the CIP engagement factors which are cooperation, interest, and participation. Overall there is a significant difference in the engagement mean scores of students before and after the implementation of PLTL. It was concluded that the use of Peer-Led Team Learning as a teaching-learning strategy has provided positive effects to the achievement and engagement of students towards learning chemistry. The workshop participants also revealed that they are felt comfortable learning under the peer leaders because they were approachable, friendly, and was able to execute the lessons properly and clearly. The students also enjoyed sharing ideas and working together with each other that triggered cooperation among them.
\end{abstract}

Keywords: achievement, chemistry, engagement, peer leader, peer learning

\section{Background}

It is observed that many high school students experience difficulties with many of the concepts in chemistry as a subject. Chemistry had been regarded as a difficult sub- 
ject for students by many researchers, teachers, and science educators because of the abstract nature of many chemical concepts, teaching styles applied in class, lack of teaching aids, and the difficulty of the language of chemistry. All these cause students, from primary level to the university, to develop poor understanding and misunderstandings and it also results in low test results and outcomes that serve as an indicator of the effectiveness of the instructions provided by teachers. Motivating students to engage and actively participate in science classroom activities is one of the major challenges teachers face daily. The purpose and importance of actively engaging students in the lesson should also be clearly understood by teachers. The fundamental aim of classroom engagement is to facilitate and stimulate maximum learning participation. When students are properly engaged in the classroom, they tend to show greater interest and participation in lessons thus leading to better performance (Carini, Kuh \& Klein, 2013).

The NAT results taken by students of Casimiro A. Ynares Sr. Memorial National High School in the school year 2016-2017 has a mean percentage score (MPS) 38.41 in Science which is the lowest in all learning areas included in examination compared with the MPS in Filipino (58.10), Mathematics (41.63), English (54.44) and Araling Panlipunan (58.45). This only proved that students are confronted with problems in dealing with Science subjects which includes Chemistry as one of the component learning areas of the subject.

The Department of Education calls for the entire nation to see the urgency of addressing the issues and gaps that surrounds the basic education sector of our country. Teachers are specially called to seriously address and take active involvement in this issue since teachers are in the frontline service of the nation's education system. How to make students enjoy and learn in a Science subject is a challenge to every teacher. The need to adopt new teaching strategies is a big challenge nowadays. Teachers should consider a shift in their daily practices and think of better strategies that will encourage students to participate actively in the lessons.

One promising teaching strategy is Peer-Led Team Learning, a model used in teaching Science and Math that introduces peer-led workshops as a remediation approach to students left behind in the class. Students who have done well in the subject are recruited to become peer leaders. The peer leaders meet with the workshop participants each 
week for one to two hours to discussed and engaged in a problem-solving activity related to their subject or topics which the participants find difficult or uninteresting.

It is in this light that the researcher decided to conduct a study to determine the effects of Peer-Led Team Learning on students' achievement in Chemistry and learning engagement of Grade 9 students of Casimiro A. Ynares Sr. Memorial National High School in Taytay, Rizal. The outcome of this study may also change the students' perception of chemistry and could serve as an eye-opener to teachers in a classroom with more than 50 diverse learners to think of ways and strategies on how to make every learning experience enjoyable in a friendly and accepting environment.

\section{Research Questions}

The main purpose of this study is to determine the effects of Peer-Led Team Learning (PLTL) on the achievement and level of engagement in Chemistry of Grade 9 students. Specifically, it sought the answer to the following questions:

1. What is the students' achievement in Chemistry before and after their exposure to PLTL?

2. Is there a difference between the pretest and posttest mean scores of students in Chemistry before and after their exposure to PLTL?

3. What is the students' engagement in Chemistry before and after their exposure to PLTL in terms of:
a. cooperation
b. interest
c. participation

4. Is there a difference between the students' pretest and posttest engagement scores in Chemistry before and after their exposure to PLTL?

5. What are the learning experiences of students on Peer-Led Team Learning? 


\section{Literature Review}

A total of 18 studies were found to be related to the present study. Fourteen of these related studies are foreign and four are local. The breakdown of the studies is presented as follows: (1) nine studies exploring PLTL on different fields of studies including science subjects and (2) nine studies revealing the relationships between engagement and science learning.

It is also important to take note that the studies of Winterton (2018), Snyder and Sloane (2016), Wells (2014), Bramaje and Espinosa (2013), Samaroo (2012), Finn and Campisi (2011), Tenney and Houck (2009) and Quitadamo, Brahler and Crouch (2009), they revealed the effectiveness and positive impact of PLTL in the teaching and learning process in the secondary and higher education science courses. Unanimously they exposed that PLTL improved the academic success of the students they've observed. Winterton stressed that the ability of peer leaders to relate to the student is an important factor in improving learning gains and in establishing a positive relationship between the workshop participants and teachers. Snyder and Sloane revealed that students in introductory biology courses performed significantly better when engaged in PLTL. There was also a drastic reduction in the failure rate of underrepresented minority students with PLTL, which further resulted in closing the achievement gap. The investigation made by Wells on the impact of Peer-Led Team Learning (PLTL) on secondary students has identified positive attitudes towards the implementation of PLTL with students reported gains in conceptual understanding, academic achievement towards learning biology topics. Bramaje and Espinosa conducted a study to assess the effectiveness of the Peer-Led Team Learning (PLTL) approach against the traditional teaching approach (TTA) in enhancing students' conceptual understanding and attitude towards chemistry, the results of the study showed that students exposed to PLTL performed better as revealed by the results of the assessment given to them. Samaroo also investigated the effectiveness of Peer-led team learning (PLTL) and it showed that students had better grade performance when PLTL was used in the course. Comparative data before and after the implementation of PLTL demonstrated improvement in grades, as well as understanding in chemical concepts, which were revealed by Tenney and 
Houck. Lastly, PLTL appeared to help underperforming students make positive gains in critical thinking, according to Quitadamo, Brahler, and Crouch.

On the other hand, the study conducted by Chan and Bauer (2015) found no difference in the exam achievement of students who participated in PLTL versus those who participated in documented alternative study activities.

Wood (2019), Espejo (2018), Schmidt, Rosenberg, and Beymer (2017), Virtanen et al., (2016), Francisco (2015), Selim (2015), Jung (2014), Reeve (2014), and Thompson and Bennett (2011) unanimously cited the importance and relationship between student engagement and science learning. Wood revealed that relatedness, cooperation, and autonomy have positive impacts on students' engagement in classroom-based learning activities. Schmidt, Rosenberg, and Beymer stressed the importance of the person-incontext approach to student engagement in science. Espejo concluded that students who perceived their learning environment to be autonomy-supportive showed significantly higher academic engagement in their classes compared to the teacher-controlled counterparts. The assessment made by Virtanen et al. to the learning engagement of junior high school provided corroborating pieces of evidence between the engagement of junior high school students to self-esteem and academic achievement.

Jung suggested that educators, policymakers, and the research community need to pay more attention to student engagement and think of ways to enhance it to improve the performance of students in school. On the other hand, Reeve in his study stated that exploring the engagement level of students is highly essential and could result in a longterm commitment to their learning goals and academic success in science. The results of the study conducted by Thompson and Bennett indicated that there is an association between students' engagement and future orientation towards learning science.

\section{Methodology}

\section{Research Design}

A single group pre-test-post-test pre-experimental research design was utilized in this study in determining the effects of Peer-Led Team Teaching (PLTL) on the chemistry achievement and learning engagement of Grade 9 students of Casimiro A. 
Ynares Sr. Memorial National High School for S.Y. 2019-2020. Quantitative analysis was used in interpreting the results of the achievement test and the student engagement instrument to measure the effects of PLTL. Qualitative analysis was utilized in describing students' experiences during and after undergoing PLTL workshops. Figure 1 presents the research design.

A single group pre-test and post-test pre-experimental research design are shown below:

\begin{tabular}{|ccl|}
\hline & $\mathbf{O}_{1}$ & \multicolumn{1}{c|}{$\mathbf{X}$} \\
where: & $\mathrm{O}_{2}$ & is the pretest (CAT and CIP) Team \\
& $\mathrm{X}_{2}$ & is the treatment (Peer Led Learning) \\
& $\mathrm{O}_{2}$ & is the posttest (CAT and CIP) \\
& & \\
\end{tabular}

\section{The Research Participants}

The students that participated in this study are Grade 9 students of Casimiro A. Ynares Sr. Memorial National High School (CAYSMNHS), a public junior high school located at the municipality of Taytay in the province of Rizal. Purposive sampling method, a non-probability sampling technique was used in selecting the participants of the study from the existing school population.

For the school year 2019-2020, Casimiro A. Ynares Sr. Memorial National High School has 14 sections in the Grade 9 level which are: Acacia, Aguho, Apitong, Banaba, Dao, Ipil-ipil, Kamagong, Lauan, Mahogany, Molave, Mulawin, Narra, Talisay and Yakal. Twelve out of the fourteen sections are heterogenous, one section (Aguho) is under the special program for journalism while the other one is the pilot section. Section Acacia served as the participants of this study. The researcher handles section Acacia which is composed of 16 male students and 20 female students.

\section{Research Instrument}


In the conduct of the study, the researcher used five research instruments: (1) Lesson Plans with PLTL features and Workshop Plans (2) CIP Engagement Instrument based from the Student Engagement Instrument (SEI) developed by Appleton and Christenson (2006), used to determine the engagement scores of students in learning science (3) Chemistry Achievement Test (CAT) developed by the researcher (4) Open-Ended Questions (OEQ) and the (5) Students' Workshop Reflection developed by Tenney and Houckin (2004). Three of the research instruments were developed by the researcher and two were adopted which are the CIP Engagement Instrument and the Students' Workshop Reflection.

\section{Peer-Led Team Learning Lesson and Workshop Plans}

Five lesson plans in Chemistry were developed by the researcher following the prescribed format stated in DepEd Order 42 series 2016 and reflective of the 4A model of learning: Activity, Analysis, Abstraction, and Application. The PLTL lesson plans with PLTL features were designed in a way that enabled students to cooperate, made use of available resources, and developed the science process skills. The lesson plans underwent face and content validation from the experts before it was formally used in the class.

The researcher also developed five workshop plants that are parallel with the lesson plans and it was likewise used in the implementation of PLTL to the class. The workshop plan is composed of four stages. Stage $I$ is the peer leaders' training, a resource for leader training which is Peer-Led Team Learning: A Handbook for Team Leaders by Roth, Goldstein, and Marcus (2001) was utilized as a guide in the study. The peer leaders' training included: content knowledge, pedagogical knowledge, pedagogical content knowledge, and leadership roles. In the content knowledge, the peer leaders were given advanced learning sessions of the concepts included in the workshops. Second, in pedagogical knowledge, the peer leaders were taught the process of teaching and learning that included motivational strategies, engaging and involving the workshop participants in the learning process. Next, is the pedagogical content knowledge, it was explained to them the specific teaching strategies and methods of teaching that were used in handling the specific content area. Lastly in the leadership 
role, it was defined to the peer leaders the roles and duties that they must accomplish in the class being the workshop facilitators. They were also thought how to properly act as workshop leaders. Since peer leaders don't have any teaching experience; the researcher gave them an insight into the teaching strategies that were used in every workshop session. The training of the peer leaders occurred during the entire duration of the study. As the study progressed, daily meetings happened at the end of every session to ensure smoothness and effective PLTL implementation. Stage I took placed weeks before the implementation of the workshop proper that was facilitated by the supervising teacher.

The peer leaders are students that are at the same grade level and section of the mentees, they were selected from the class by determining the stanine score of students using their final grade in Science Grade 8 as the input score. Based on the summary of the stanine score, the two peer leaders have a score that is verbally interpreted as high. Aside from having a high stanine score, another basis for choosing the peer leaders are the positive character, discipline, and confidence demonstrated by the students during the first quarter. The class adviser and other subject teachers were also consulted and unanimously agreed on the capabilities of the two peer leaders.

Stage II is the preparation of workshop materials, at least three days were allotted for the preparation of materials needed for the lesson and this was assisted by the supervising teacher. Stage III is Peer-Led Team Learning (PLTL) workshop proper that was done from 8:30 to 9:20 in the morning at their classroom, during the workshop proper the researcher was not present inside the classroom to avoid contaminating and meddling the lessons. The workshop proper followed a systematic pedagogical process that included a review of the previous lesson, activity proper, discussion, analysis of guide questions, abstraction, and application.

The PLTL Workshop was divided into a 5-week session. Each week has a certain activity and was facilitated using a specific teaching strategy. The developed lesson plans and workshop plans were presented to the researchers' mentor and other experts for content validation.

The PLTL workshop commenced with the lesson atomic models as their first workshop session, focusing on the models proposed by Rutherford, Bohr, and Schrodinger. The students constructed different atomic models using simple available materials like paper plates and colored papers. The teaching strategies used in the first 
workshop session are a group activity, scientific modeling, art integration, and gallery walk.

The second workshop was about the electronic structure of matter with two topics, the first topic is about the electron configuration of elements belonging to Groups 1-8 and the second topic is on how to represent the spin of electrons following Hund's Rule. Group activity and interactive discussions were used in facilitating the second workshop.

The third workshop was about Lewis dot symbol and electronegativity. The peer leader used group activity, interactive discussions, and picture analysis in facilitating the third workshop.

The fourth and fifth workshop was about chemical bonding; ionic and covalent bond. The students used PhET interactive simulations and group activity during the workshops and this was done at the school computer laboratory.

All workshop materials were provided by the teacher and other instruction materials were prepared by the peer leaders with the supervision of the teacher.

\section{Cooperation-Interest-Participation (CIP) Engagement Instrument}

The Cooperation-Interest-Participation (CIP) engagement instrument was based on the Student Engagement Instrument (SEI) developed by Appleton and Christenson in 2006. The original SEI is composed of 35 item question statements and is divided into six factors, which are the Control and Relevance of School Works, Future Aspirations and Goals, Extrinsic Motivation, Teacher Student Relation, Family Support for Learning and Peer Support at School. Karim (2013) examined the factor structure of the Student Engagement Instrument (SEI) using the Malaysian sample. The results showed that the SEI has enough internal consistency, with an overall Cronbach alpha $(\alpha)$ value of .900. Two factors were considered from the instrument because it is the most appropriate in this study, the Control and Relevance of School Work (CRSW) factor, which is composed of nine-question statements and the six-item Peer Support for Learning (PSL) factor. The 15 items adopted questions had undergone reclassification into cooperation, interest, and participation. The reclassification was based on the available literature on the internet and it was further validated by experts. 
The CIP engagement instrument is a four-point scale, self-assessment tool that was used to determine the engagement scores of students in learning chemistry as a subject in school. The students responded to the instrument by checking one of the four categories ranging from Strongly Agree (4), Agree (3), Strongly Disagree (2), and Disagree (1).

\section{Chemistry Achievement Test (CAT)}

An achievement test is a test that measured the student's achievement and progression about the identified topics in Grade 9 second quarter Science (Chemistry). In this study, a 40-item multiple-choice competency-based examination developed by the researcher was used as an achievement test. The CAT was developed based on a prepared table of specifications (TOS) which measured three domains of learning, specifically: remembering, understanding, and applying. It covered five learning competencies which are (1) describe how the Bohr Model of the atom improved Rutherford's atomic model, (2) explain how the quantum mechanical model of the atom describes the energies and positions of the electrons, (3) explain the formation of ionic and covalent bonds (4) recognize different types of compounds (ionic or covalent) based on their properties such as melting point, hardness, polarity, and electrical and thermal conductivity and (5) explain how ions are formed. The CAT underwent face and content validation by seeking opinions from the adviser of the researcher. Comments and suggestions were considered in the preparation of the final draft of the test. The original 70 items first draft CAT was pilot tested to one of the Grade 9 sections, the students took the examination before the end of the school year 2018-2019. After the pilot testing of the CAT, results of the item analysis showed that nine items must be rejected and 20 need to be revised. The remaining 41 were retained.

Items with a difficulty index of 0.21-0.80 and a discrimination index of 0.30 and above were included in the final draft of CAT consisting of 40 items. In the final draft of CAT, 11 items (27.5\%) were adapted from the learning module provided by the Department of Education, while the 29 items (72.5\%) were originally constructed by the researcher. The final draft has undergone a reliability test using the Kuder-Richardson 
Formula 20. The reliability estimate of the final draft of CAT is .7881 which indicates that the test has high reliability.

Open-Ended Questions (OEQ)

Five open-ended questions were used to find out how the workshop participants understood or feel about the situation, people, or environment that they have experienced during the conduct of the research study. The OEQ was employed after the implementation of PLTL and it was validated first by the researcher's adviser and research panels before employing the students. All students took the OEQ but the response from six randomly selected students were considered in this research. Their response was compared with the results of their answer to the student engagement instrument and was treated as qualitative data.

\section{Students’ Workshop Reflection}

The students' workshop reflection is an instrument that was adopted from Tenney and Houck (2004) and it appeared on the paper of Hooker in 2006. It is a 15 item, fourpoint scale, self-assessment tool that was used to evaluate the performance of the peer leaders. It was given every week after the end of each workshop topic. The students responded to the instrument by checking one of the four categories ranging from Strongly Agree (4), Agree (3), Strongly Disagree (2), and Disagree (1). The minimum score for this instrument is 15 and the maximum is 60 . The range of means score in every evaluation done by the research participants to the peer leaders was described using the following verbal interpretation or remarks:

$$
\begin{array}{lll}
3.3-4.0 & = & \text { Strongly Agree } \\
2.5-3.2 & = & \text { Agree } \\
1.7-2.4 & = & \text { Disagree } \\
1.0-1.6 & = & \text { Strongly Disagree }
\end{array}
$$

\section{Data Analysis}

To determine the achievement of the students that was measured by the CAT, a pretest and post-test was administered, the scores of the students were individually 
checked, scored, totaled, and recorded. Mean, standard deviation, highest and lowest scores obtained were described and compared analytically.

On the other hand, the engagement scores of students in each factor were calculated by adding their scores to the questions. The cooperation factor is composed of four questions, interest has nine, and participation in two. The overall engagement scores of students were determined by adding the scores in all 15 questions.

The reaction, interest, and involvement of students in chemistry after undergoing PTLT were determined using open-ended questions. The open-ended questions were utilized to gather the responses of the participants towards learning chemistry under the Peer-Led Team Learning strategy and to generate common ideas regarding the situations given to them. All participants answered the open-ended questions, but answers with a common theme were summarized.

The 15-item workshop reflection was given to all students after the end of every workshop. There were five workshop reflection scores collected in this study. The mean score per question was obtained by adding the scores of students and dividing it by the number of raters. The weekly workshop reflection mean score was attained by adding the total scores of all students and dividing it by the number of raters. The five weekly mean score was added to get the overall mean score in the workshop reflection.

\section{Statistical Treatment}

The data in this study were obtained from the Chemistry Achievement Test, CIP Engagement Instrument, Open-Ended Questions, and Students' Workshop Reflection. The gathered data were grouped, tabled, and carefully organized, and interpreted by the researcher which served as the basis for the drawing of conclusions. Frequency, percentage, and ranking are all reflected in tabular forms. Gathered raw quantitative data were statistically processed and analyzed using MS EXCEL software. Descriptive and inferential statistics were used to treat the data for the basis of interpretation. KuderRichardson Formula 20 was used to determine the reliability of the Chemistry Achievement Test. The $t$-test for paired samples was applied to be able to compare the achievement of students in Chemistry, mean scores for each engagement factor, and 
Lamina, O.G. (2021). Peer-led team learning (pltl), student achievement and engagement in learning chemistry, International Journal of Quality in Education

overall engagement level of students based on the results of the pre-test and post-test given to them. All test of difference was evaluated at 0.05 level of confidence.

\section{Results}

\section{Students' Achievement in Chemistry}

The achievement test in the form of pretest and posttest was utilized to determine the performance of the students in Chemistry before and after their exposure to Peer-Led Team Learning (PLTL) strategy. The pretest and posttest of each student are shown in Appendix J. Table 4 shows the summary of the descriptive statistics based on the results of the pretest and posttest given to students.

Table 1.

Descriptive statistics of the pretest and posttest scores of the students in the chemistry achievement test $(N=36)$

\begin{tabular}{cccccc}
\hline Test & $\begin{array}{c}\text { Highest } \\
\text { Score }\end{array}$ & $\begin{array}{c}\text { Lowest } \\
\text { Score }\end{array}$ & Mean & $\begin{array}{c}\text { Mean Dif- } \\
\text { ference }\end{array}$ & SD \\
\hline Posttest & 39 & 18 & 26.06 & & 6.03 \\
Pretest & 24 & 5 & 13.83 & & 4.61 \\
\hline
\end{tabular}

Table 1 presents the results of the 40-item Chemistry achievement test administered to the research participants. The highest score obtained on the posttest given is 39 while the lowest is 18 . The computed mean or the average of the scores is 26.06 the standard deviation is 6.03. On the other hand, the highest score obtained on the given pretest is 24 and the lowest is 5. The computed mean or the average of the scores is 26.06 the standard deviation is 6.03 . The computed mean or average of the scores is 13.83 and the standard deviation is 4.61 . The difference between the mean of the pretest and posttest is 12.23 , this shows that there is an increase in the scores of the students after the implementation of Peer-Led Team Learning. In addition, the computed standard 
Lamina, O.G. (2021). Peer-led team learning (pltl), student achievement and engagement in learning chemistry, International Journal of Quality in Education

deviation of the scores in the posttest has become spread out or scattered compared to the scores of the pretest.

To determine whether the performance of students in the pretest and posttest is statistically significant, paired $t$-test for grouped data was employed. The results of the test are summarized in Table 2:

Table 2. The paired t-test between the students' pretest and posttest in CAT $(N=36)$

\begin{tabular}{ccccccc}
\hline Test & Mean & SD & df & $t$-value & $p$-value & Remarks \\
\hline Posttest & 26.06 & 6.03 & & & & \\
& & & 35 & 13.83 & 0.000 & Significant \\
Pretest & 13.83 & 4.61 & & & & \\
\hline p $<0.05$ significance & & & & & &
\end{tabular}

As presented in Table 2, the computed $t$-value is 13.83, while the $p$-value is 0.000 which is less than the 0.05 level of significance $(\mathrm{p}<0.05)$ set in this study. This indicates that there is a significant difference between the scores of students on the Chemistry achievement test administered to them before and after their exposure to the Peer-Led Team Learning (PLTL) strategy. The result of the achievement test also revealed that the students performed better on the posttest compared to the pretest and this affirms the effectiveness of PLTL as a teaching-learning strategy in science for Grade 9 junior high school students. The outcomes of the study are also supported by the findings of the research conducted by Wells (2014) that investigated the impact of Peer-Led Team Learning (PLTL) on secondary school students' conceptual understanding of biology concepts. Gathered data have identified positive results towards the implementation of PLTL, with students reported gains in conceptual understanding and academic achievement. Moreover, PLTL was generally effective in supporting the academic success of students in science subjects. The results of the study of Snyder and Sloane (2015) also confirmed that PLTL has a positive effect on students because it helped improved performance and engagement in science subjects by the interaction of the participants with the peer leaders and being involved in problemsolving situations and open discussions. The study also conforms with the findings of 
Lamina, O.G. (2021). Peer-led team learning (pltl), student achievement and engagement in learning chemistry, International Journal of Quality in Education

Frey, Fink, and Solomon (2018) that showed robust evidence that Peer-Led Team Learning (PLTL) improved the academic success of students in Science and Technology and Mathematics subjects.

\section{Students' Engagement in Learning Chemistry}

To determine the engagement mean score of students in chemistry before and after their exposure to PLTL, the Cooperation-Interest-Participation (CIP) engagement instrument was utilized. The engagement of students in each factor in the pretest and postest were individually analyzed and summarized on the succeeding tables.

Table 3. The mean and standard deviation of the cooperation factor

\begin{tabular}{lccc}
\hline Test & Mean Score & Mean Difference & SD \\
\hline Posttest & 14.67 & \multirow{2}{*}{3.23} & 1.62 \\
Prettest & 11.44 & & 1.80 \\
\hline
\end{tabular}

As shown in Table 3, the mean score in the posttest of the cooperation factor is 14.67 with a standard deviation of 1.62 , while the mean score in the post-test is 11.44 with a standard deviation of 1.80. It can be noticed that there is an increase in the mean scores of the pretest and posttest (the mean difference is 3.23) in the cooperation factor.

Table 4. The mean and standard deviation of interest factor

\begin{tabular}{lccc}
\hline Test & Mean Score & Mean Difference & SD \\
\hline Posttest & 32.22 & \multirow{2}{*}{3.66} & 2.90 \\
Prettest & 28.56 & & 3.63 \\
\hline
\end{tabular}

As presented in Table 4, the mean score in the posttest of the interest factor is 32.22 with a standard deviation of 2.90 , while the mean score in the pretest is 28.56 with a standard deviation of 3.63. It is clearly shown that there is an increase in the mean scores of the pretest and posttest (the mean difference is 3.66) of the interest factor.

Table 5. The mean and standard deviation of the participation factor

\begin{tabular}{llll}
\hline Test & Mean Score & Mean Difference & SD \\
\hline
\end{tabular}


Lamina, O.G. (2021). Peer-led team learning (pltl), student achievement and engagement in learning chemistry, International Journal of Quality in Education

\begin{tabular}{llll}
\hline Posttest & 7.63 & 1.1 & 0.79 \\
Prettest & 6.53 & 1.16 \\
\hline
\end{tabular}

As revealed in Table 5, the mean score in the posttest mean score of the participation factor is 7.63 with a standard deviation of 0.79 , while the mean score in the pretest is 6.53 with a standard deviation of 1.16 . It can be seen that there is an increase in the mean scores of the pretest and posttest (the mean difference is 1.1) of the participation factor.

Table 6. CIP overall mean and standard deviation

\begin{tabular}{lccc}
\hline Test & Mean Score & Mean Difference & SD \\
\hline Posttest & 54.25 & \multirow{2}{*}{7.72} & 4.09 \\
Prettest & 46.53 & & 4.53 \\
\hline
\end{tabular}

As shown in Table 6, the overall mean score in the posttest is 54.25 with a standard deviation of 4.09 , while the mean score in the pretest is 46.53 with a standard deviation of 4.53. It can be noticed that there is an increase in the overall mean of the pretest and posttest (mean difference is 7.72) engagement scores of students.

To further examine the results of the pre and post engagement of the student participants, the mean scores of each factor were individually analyzed using paired ttest for grouped data to be able to determine if there is a significant difference between the scores. The results of the test are given in the table below:

Table 7. The paired t-test between the students' pretest and posttest mean score in the CIP $(N=36)$

\begin{tabular}{|c|c|c|c|c|c|c|}
\hline $\begin{array}{l}\text { Engagement } \\
\text { Factors }\end{array}$ & $\begin{array}{c}\text { Posttest } \\
\text { Mean } \\
\text { Score }\end{array}$ & $\begin{array}{c}\text { Pretest } \\
\text { Mean } \\
\text { Score }\end{array}$ & df & $t$-value & $p$-value & Remarks \\
\hline Cooperation & 14.67 & 11.44 & 35 & 9.27 & 0.000 & Significant \\
\hline Interest & 32.22 & 28.56 & 35 & 5.27 & 0.000 & Significant \\
\hline Participation & 7.36 & 6.53 & 35 & 3.46 & 0.000 & Significant \\
\hline Overall & 54.25 & 46.53 & 35 & 8.77 & 0.000 & Significant \\
\hline
\end{tabular}


As presented in Table 7, the computed t-value for the cooperation factor of the CIP engagement instrument is 9.27 while the p-value is 0.000 , which is lower than the 0.05 $(p<0.05)$ level of significance set in this study, this indicates that there is a significant difference in terms of the mean scores of the cooperation factor before and after the exposure of students to PLTL. On the interest factor, the computed t-value is 5.27 while the $p$-value is 0.000 which is also lower than the $0.05(\mathrm{p}<0.05)$ level of significance, this is a strong indication that there is a significant difference in terms of the interest factor that affected the engagement of students in learning chemistry. Furthermore, the computed t-value for the participation factor is 3.46 while the p-value is 0.000 which is also lower than $0.05(\mathrm{p}<0.05)$, the result likewise indicates that there is a significant difference in the participation factor of engagement students before and after their exposure to PLTL.

The overall results of the CIP engagement instrument revealed that there is a significant difference in the engagement mean scores of students before and after their exposure to PLTL with a t-value of 8.77 and a p-value result of 0.000 that is lower than $0.05(\mathrm{p}<0.05)$ level of significance. It can be inferred from the analysis of the overall pre and post-mean scores of the CIP engagement instrument that the Peer-Led Team learning strategy significantly improved the engagement of students in learning Chemistry.

The results of the study are also parallel with the findings of Hampden-Thompson and Bennett (2011) that understanding the students' engagement in science and the factors that influence learning is essential in addressing the issue of improving the achievement of students towards a subject. Reeve (2012) revealed that teachers should explore the factors that contribute to the learning of students because it is essential to their long-term commitment and their learning goals. Furthermore, according to him that prosocial approaches affect the academic success of students in science. Finn and Campisi (2011) showed that active learning strategies such as PLTL can improve student learning engagement and not adversely affected student performance in science.

\section{Students' Response to the Open-Ended Questions}


To further validate the results of the quantitative analysis, five open-ended questions were employed. The researcher developed the open-ended questions and it was validated by the researchers' adviser and panel members. The open-ended questions were utilized to gather the responses of the participants towards learning chemistry under the Peer-Led Team Learning strategy and to generate common ideas regarding the situations given to them. All participants answered the open-ended questions, but answers with a common theme were summarized. In this study, the posttest engagement scores were taken and served as the basis for the grouping of students into high and low ability groups.

Based on the response of both high and low ability students, the peer leaders helped improve their performance in chemistry because they felt more comfortable whenever their classmates speak in front of the class and it helped eased the feeling of intimidation brought about by the too much formality in the classroom established by their teachers. The students also enjoyed sharing ideas and working with each other that triggered cooperation among them. The workshop participants also revealed that the peer leaders during the lessons are approachable and they were able to execute the lessons clearly and vividly because they know the topics assigned to them very well. Furthermore, based on the open-ended questions, they felt no pressure and they were not hesitant and gained the freedom to express their ideas inside the classroom.

According to the high ability group, they experienced no problems during the implementation of Peer-Led Team Learning because the peer leaders were able to maintain order inside the classroom and they focused on finishing the assigned task to them and listening to the peer leaders. On the other hand, based on the answer of the students in the low ability group they experienced problems during the workshop implementation like being bored during discussions because of the peer leaders being mild and tolerant to the noisy students. They also find that the peer leaders not as good as the teacher when it comes to information sharing and giving more details about a topic which resulted in some confusion.

The students believed that Peer-Led Team Learning workshops improved their engagement in learning Chemistry because they interacted, shared ideas, and cooperated with their groupmates and other students in performing and accomplishing the activities assigned to them. Difficult topics that are hard to understand became easier with the 
help of their peer leaders and other students. By interacting and sharing ideas the students were also able to correct their misunderstandings and confusions about the chemistry topics.

Both groups of students unanimously revealed that the most interesting Peer-Led Team Learning topics are the atomic models and electron configuration. According to them, those topics are easiest and the most interesting, they also enjoyed learning them because in those topics they made models and representations of the sub-particles of matter that are impossible to be seen in real life. The activities provided to them stirred their curiosity and triggered them to do more research and information regarding those topics.

The students also recommend the use of Peer-Led Team Learning workshops to students of other Grade 9 sections because based on their experience it resulted from a positive impact on their learning engagement and improved their performance in chemistry. The students believed that learning is more exciting and fun when it is done with friends compared to formal learning. PLTL also improved the relationship and cooperation among and between students by openly sharing and soliciting ideas and information with one another.

It can be deduced from the summary of the student's responses to the open-ended questions that the students perceived the teaching strategy positively because the majority of the students reported that the strategy has increased their cooperation, interest, participation and allowed them to be more active in the classroom.

\section{Results of the Students' Workshop Reflection}

To ensure the quality of the implementation of the Peer-Led Team Learning and the competence of the peer leaders, and adopted workshop reflection tool was administered to the workshop participants. The workshop reflection is a 15 item, four-point scale, self-assessment tool given after the end of each workshop. The students responded to the instrument by checking one of the four categories ranging from Strongly Agree (4), Agree (3), Strongly Disagree (2), and Disagree (1). The total response scores in every question were shown to the peer leaders and they were asked to reflect on it for improvement. The response is summarized in Table 8 . 
As presented in Table 8 the overall mean score based on the response of students to the workshop reflection tool conducted for five weeks is 3.42 which indicates that they strongly agree and are satisfied with the performance of the peer leaders and the implementation of PLTL. Data revealed that question number 8 obtained the highest rating with a 3.58 mean response, the workshop participants strongly agreed that the peer leaders were not intimidating and friendly to them during the implementation of the PLTL workshops.

Table 8. Summary of the students' workshop reflection $(N=34)$

\begin{tabular}{|c|c|c|}
\hline Items & $\begin{array}{c}\text { Mean } \\
\text { Response }\end{array}$ & Remarks \\
\hline $\begin{array}{l}\text { 1. The team leaders are intimidating and unfriendly } \\
\text { to the workshop participants. (reversely scored) }\end{array}$ & 3.58 & Strongly Agree \\
\hline $\begin{array}{l}\text { 2. The workshop materials are well connected and } \\
\text { appropriate to the lesson. }\end{array}$ & 3.55 & Strongly Agree \\
\hline $\begin{array}{l}\text { 3. Interacting and listening to the workshop leaders } \\
\text { increase my understanding of chemistry. }\end{array}$ & 3.54 & Strongly Agree \\
\hline $\begin{array}{l}\text { 4. The venue is well lighted and ventilated and is } \\
\text { conducive for learning. }\end{array}$ & 3.54 & Strongly Agree \\
\hline $\begin{array}{l}\text { 5. The workshop leaders are effective in leading the } \\
\text { workshop. }\end{array}$ & 3.53 & Strongly Agree \\
\hline $\begin{array}{l}\text { 6. The workshop materials are sufficient and } \\
\text { appropriate for the topic. }\end{array}$ & 3.51 & Strongly Agree \\
\hline $\begin{array}{l}\text { 7. I agree with the explanation and information that } \\
\text { the leader gives during the sessions. }\end{array}$ & 3.51 & Strongly Agree \\
\hline $\begin{array}{l}\text { 8. The workshops are improving my understanding } \\
\text { and performance in chemistry. }\end{array}$ & 3.48 & Strongly Agree \\
\hline 9. The workshop leaders are well prepared. & 3.46 & Strongly Agree \\
\hline $\begin{array}{l}\text { 10. I am satisfied with the learnings I get from } \\
\text { every workshop session. }\end{array}$ & 3.46 & Strongly Agree \\
\hline $\begin{array}{l}\text { 11. I would recommend a Peer-Led Team Learning } \\
\text { workshop to other students. }\end{array}$ & 3.45 & Strongly Agree \\
\hline $\begin{array}{l}\text { 12. Interacting with other group members increases } \\
\text { my understanding of chemistry. }\end{array}$ & 3.42 & Strongly Agree \\
\hline $\begin{array}{l}\text { 13. In the workshops, I am comfortable asking } \\
\text { questions about the topic that I do not } \\
\text { understand. }\end{array}$ & 3.42 & Strongly Agree \\
\hline $\begin{array}{l}\text { 14. I help explain problems to other students during } \\
\text { the workshop. }\end{array}$ & 3.34 & Agree \\
\hline $\begin{array}{l}\text { 15. Noise or other students do not distract me } \\
\text { during the workshop. }\end{array}$ & 2.55 & Agree \\
\hline Overall mean & 3.42 & Strongly \\
\hline
\end{tabular}


Question number 2 got the second-highest mean response score of 3.55 from the students, they strongly agree that the materials prepared by the peer leaders is appropriate and connected to the topics they handled, and it is also supported by the response in question 6 (3.51) that the workshop materials were enough for the needs of students. Questions number 3 and 4 got a mean score rating of 3.54, the students strongly agreed that interacting and listening to the peer leaders helped increase their understanding of the chemistry topics and the venue for the PLTL workshop was conducive for learning. The workshop participants also revealed thru questions number 7 and 8 that they strongly agree with the explanations and information that their leaders provided during the sessions and the workshops help improve their understanding and performance in Chemistry. However, it was revealed by question number 15 which obtained the lowest mean response score that students were distracted by the noise of other students during the workshops. In general, the workshop participants strongly agreed that the PLTL strategy helped improve their understanding and performance in Chemistry because of the non-intimidating and friendly atmosphere they've experienced. The students were also comfortable interacting, asking questions, and sharing information with the workshop leaders and other participants.

\section{Conclusions}

Based on the summary of findings the corresponding conclusions were drawn.

1. Peer-led team learning strategy improved the performance of Grade 9 students in chemistry.

2. The exposure of students to peer-led team learning strategy improved their engagement in learning chemistry.

3. Students tend to favor the use of PLTL in learning chemistry. They strongly agreed that the peer leaders help improve their performance and engagement in learning chemistry.

4. Cooperation, interest, and participation are contributors to the learning engagement of students in chemistry. 


\section{Recommendations}

Based on the summary of findings and conclusions drawn, the following recommendations are hereby recommended:

1. Encourage teachers to use the Peer-Led Team Learning strategy in teaching chemistry since it was found to be effective in improving the students' performance.

2. Conduct similar PLTL research studies using other topics in chemistry to further assess the effectiveness of PLTL in teaching science.

3. Undertake additional studies using the larger sample to verify the results of the study.

4. Replicate this study using other grade level or in another learning area to assess the effectiveness of PLTL

5. Adopt the PLTL activities developed in the study to further validate the results.

\section{References}

Ainley, M. \& Ainley, J. (2011). Student engagement with science in early adolescence: The contribution of enjoyment to students' continuing interest in learning about science. Contemporary Educational Psychology.

Bramaje, G. \& Espinosa, A. (2013). Peer-led team learning approach: Effects on students' conceptual understanding and attitude towards chemistry. International Journal on Teaching and Learning.

Bryson, C. \& Hand, L. (2007). The role of engagement in inspiring teaching and learning. Innovations in Education and Teaching International.

Carini, R., Kuh, G., \& Klein, S. (2013). Student engagement and student learning: Testing the linkages. Research in Higher Education,

Chan, J. (2015). Effect of peer-led team learning (PLTL) on student achievement, attitude and self-concept in college general chemistry in randomized and quasi experimental designs. Journal Research in Science Teaching.

Christenson, S., Thurlow, M., Sinclair, M., Lehr, C., \& Kaibel, C. (2008). The intervention manual and guide for check \& connect A comprehensive student 
engagement intervention. Minneapolis: Institute on Community Integration, The University of Minnesota.

Cracolice, M. \& Deming, J. (2001). Peer-led team learning. Journal of Science Teacher.

Department of Education (2013). K to 12 Curriculum Guide in Science. Pasig City: DepEd.

Department of Education (2014). Science Module Grade 9. Pasig City: DepEd.

Department of Education (2016). DepEd Order 42 series 2016. Pasig City: DepEd.

Eberlein, T., Kampmeier, I., Minderhout, V., Moog, R., Platt, T., (2008). Pedagogies of engagement in science. Biochemistry and Molecular Biology Education.

Espejo, N. (2018). The difference in academic engagement among college students as a function of the learning environment. DLSU Research Congress Proceedings.

Finn, K. \& Campisi, J. (2012). Implementing and evaluating a peer-led team learning approach in undergraduate anatomy and physiology. Journal Research in Science Teaching.

Fitzgerald A. (2012) Teaching for Student Engagement in Science. In: Science in Primary Schools. SensePublishers, Rotterdam.

Francisco, M., Gonzales, R. \& Vargas, M. (2015). Student engagement: associations with teachers and peers as motivators. International Journal of Educational Investigations.

Frey, R. et al. (2016). Peer-led team learning in general chemistry: Interactions with identity, academic preparation, and a course-based intervention. Journal of Chemistry Education.

Fredricks, J., Blumenfeld, P., \& Paris, A. (2004). School Engagement: Potential of the concept, and state of the evidence. Review of Educational Research.

Gafney, L. \& Varma-Nelson, P. (2008). Peer-led team learning: evaluation, dissemination, and institutionalization of a college-level initiative. Springer Science \& Business Media.

Garcia-Reid, P. (2005). School engagement among Latino youth in an urban middle school context: Valuing the role of social support. Education and Urban Society Journal.

Gosser, D. (2001). Peer-Led Team Learning: A Guidebook. Upper Saddle River, NJ: Prentice-Hall. 
Gunuc, S. (2013). Determining the role of technology in student engagement and examining the relationships between student engagement and technology use in class. Unpublished Doctorate Thesis, Anadolu University, Turkey.

Hadzigeorgiou, Y. (2015). Young children's ideas about physical science concepts. Research in Early Childhood Science Education.

Hattie, J. (2003). Visible learning for teachers: Maximising impact on learning. London: Routledge.

Heller, R., (2003). Academic achievement in the middle grades: What does research tell us? A review of the literature. Atlanta, GA: Southern Regional Education Board. Retrieved from http://www.sreb.org/programs/hstw/publications/pubs/.

Hernandez, J. (2016). Students' performance and anxiety level in chemistry using peer-assisted learning strategy. Unpublished Master's Thesis, Technological The University of the Philippines Manila.

Hooker, S. (2007). The effectiveness of peer-led team learning workshops: An action research approach. Journal on Education and Human Development.

Jung, L. (2014). The relationship between student engagement and academic performance: Is it a myth or reality? The Journal of Educational Research.

Karim, M. (2013). Factor structure of the student engagement instrument among Malaysian undergraduates. Unpublished Master's Thesis, International Islamic The University of Malaysia.

Kuh, G. (2005). The national survey of student engagement: Conceptual framework and overview of psychometric properties. The Journal of Higher Education.

Lara, M. (2014). Peer-led team learning in a problem-solving course: lessons learned. Journal Research in Science Teaching.

Lynch, M. (2016). Children's relationships with adults and peers: An examination of elementary and junior high school students. Journal of School Psychology.

Matthews, K., Andrews, V. \& Adams, P. (2011). Social learning spaces and student engagement. Higher Education Research \& Development.

Marks, H. (2008). Student engagement in instructional activity: Patterns in the elementary, middle, and high school years. American Educational Research Journal.

Osborne, J. and Collins, S. (2001). Pupils' views of the role and value of the science curriculum: A focus group study. International Journal of Science Education.

Quitadamo, I., Brahler, C. \& Crouch, G. (2009). Peer-led team learning: A 
prospective method for increasing critical thinking in undergraduate science courses. Journal Research in Science Teaching.

Reeve, J. (2012). Assessing students' engagement: A review of instruments with psychometric qualities. International Perspectives of Psychology and Education.

Roth, V., Goldstein, and Marcus, G. (2001). Peer-led team learning: A handbook for team leaders. Prentice-Hall: USA.

Samaroo, S. (2012). Peer-led team learning: A general chemistry approach. Journal Research in Science Teaching.

Schmidt, J., Rosenberg, J. \& Beymer, P. (2017). A person-in-context approach to student engagement in science: Examining learning Activities and choice. Journal Research in Science Teaching.

Selim, G. (2015). The relationships between student engagement and their academic achievement. International Journal on New Trends in Education and Their Implications.

Smith, J. et al (2014). Replicating peer-led team learning in cyberspace: Research opportunities and challenges. Journal Research in Science Teaching.

Snyder, J. \& Sloane, J. (2016). Peer-led team learning helps minority students succeed. International Journal on Teaching and Learning.

Stevenson, C. (2015). The Social psychology of citizenship, participation and social exclusion: Introduction to the special thematic section. Journal of Social and Political Psychology.

Stivaktakis, S. (2008). Encouraging involvement with school science. Research in Early Childhood Science Education

Tenney, K \& Houck, B. (2004). Learning about leadership: Team learning effects on peer leaders. Journal of. College Science Teaching.

Tenney, K \& Houck, B. (2009). Peer-le team learning in introductory biology and chemistry course: A parallel approach. The Journal of Mathematics and Science: Collaborative Explorations.

Thompson, G. \& Bennett, J. (2011). Science teaching and learning activities and students' engagement in science. International Journal of Science Education.

Tien, L. \& Roth, V. (2012). Implementation of a peer-led team learning instructional approach in an undergraduate organic chemistry course. Journal Research in Science Teaching.

Tien, L. et al (2002). A course to prepare peer leaders to implement a student-assisted 
Lamina, O.G. (2021). Peer-led team learning (pltl), student achievement and engagement in learning chemistry, International Journal of Quality in Education

learning method. Journal of Chemical Education.

Wang, M., \& Holcombe, R. (2010). Adolescents' perceptions of the school environment,

engagement, and academic achievement in middle school. American Educational Research Journal.

Wells, T. (2012). Peer-led team learning as an instructional strategy for secondary school science. Journal Research in Science Teaching.

Winterton, C. (2018). Peer-Led Team Learning: The effect of peer leader and student interactions on student learning gains and course achievement in introductory biology. International Journal on Teaching and Learning.

Wood, R. (2019). Students' motivation to engage with science learning activities through the lens of self-determination theory: Results from a single-case schoolbased study. Eurasia Journal of Mathematics, Science, and Technology

Education.

Virtanen, C. et al., (2016). Assessment of student engagement among junior high school students and associations with self-esteem, burnout, and academic achievement. Journal for Educational Research.

Zepke, N., Leach, L. \& Butler, P. (2010). Student engagement: What is it and what influences it? Teaching and Learning Initiatives. retrieved from http://www.tlri.org.nz/sites/default/files/ projects 